\title{
Metaphor AND FOREIGN LANGUAgE TEACHING
}

\section{(Metáfora e o ensino de línguas estrangeiras)}

\author{
Emilia M. P. FARIAS \\ (Universidade Federal do Ceará - BRAZIL) \\ Paula Lenz Costa Lima \\ (Universidade Estadual do Ceará - BRAZIL)
}

\begin{abstract}
This article gives special attention to how the understanding of some conceptual metaphors which are found in languages typologically different can contribute to the process of teaching and learning vocabulary. Our central issue is that man's philogenetical and ontogenetical history play an important role in the generation of the concepts. If it is possible to explain cross-linguistic commonalities between typologically unrelated languages based on conceptual metaphors, then learners are stimulated to gain knowledge about how language systems are organised. The main benefit of such focused instruction is that it can raise learner's awareness of the explicit knowledge that is being consciously constructed and eventually transferred to different languages encouraging him to reach a higher level of performance.
\end{abstract}

Key-words: cognitive linguistics; metaphor in thought; metaphor in language; teaching and learning metaphor.

Resumo: Este artigo tece algumas considerações sobre como a compreensão de algumas metáforas conceptuais encontradas em línguas de origem tão distante pode contribuir para o processo de ensinolaprendizagem do vocabulário. O ponto central de nossa argumentação sustenta-se na crença em favor do compartilhamento de aspectos filogenéticos e ontogenéticos do homem. Se é possivel identificar conceitos metafóricos semelhantes em línguas de origens tão diversas, a tarefa de direcionar a atenção dos aprendizes para a forma como os sistemas linguísticos se organizam pode tornar-se mais racional. O benefício mais importante em uma instrução focalizada é o de tornar o aprendiz consciente a respeito do conbecimento que está sendo construído explicitamente e encorajá-lo a transferir esse conbecimento para outras línguas na busca de atingir um nível de performance mais elevado.

Palavras-chave: lingüistica cognitiva; metáfora no pensamento; metáfora na linguagem; o processo de ensino-aprendizagem de metáfora. 


\section{INTRODUCTION}

In the last decades, metaphorical language has been conceptualized as ways of revealing pervasive patterns of experience that serve as basis to our understanding of how the human totality comprises body, mind and world. This cognitive perspective has derived from two different commitments: the generalization commitment and the cognitive commitment. (Lakoff 1990).

The generalization commitment is the emphasis to seek general principles to describe theoretical linguistic phenomena and the cognitive commitments is the emphasis to incorporate data from different disciplines in the theoretical descriptions of the linguistic phenomena.

In this sense, language is understood as "creative acts which result from discursive practices which are constructed and reconstructed in interactive and collaborative ways by individuals in real use." (Farias \& Marcuschi, 2006a).

In line with Mey (2006:57), metaphors are kinds of embodiment, i.e., "an act by which we make our thoughts and words take bodily shape, making our actions reflect themselves in thought and words, and those words and thoughts being thrown back at us through our bodies." Undoubtedly, language performs complex functions such as social, affective and aesthetic which in turn fulfill the more comprehensive objectives of representing and communicating shared and individual experiences.

As so, our interest is to argue in favour of studying metaphor not as a means of describing linguistic systems across languages per se, but as a means of studying languages so that common conceptual processes that build those systems be revealed. In this sense, the evolutionary process can be a clue to our inherited ways of generalizing about the world and our circumstances.

If these ways uncover metaphorical thought which is a fundamental part of our reasoning, then we should refer to the findings as peculiarities of human nature. According to Lakoff and Johnson (1999:17), our reason is "inextricably tied to our bodies and the peculiarities of our brain [... . which tell us that our bodies, brain, and the interactions with our environment provide the mostly unconscious basis for our everyday metaphysics." This is exactly what we mean by reality. 
If we consider this fact, it is possible to identify patterns of thought present in various languages which are part of aspects of life shared by humans. As a result, those patterns uncover the relation between thought and language and lead to intriguing perspective of the possibility of pinpointing universal patterns of conceptualization.

Let us view the specific case of emotions which have been treated as one of the most pervasive aspects of human experience and as being so has been a distinctive object of research within the framework of cognitive linguistics. As Strugielska and Alonso-Alonso (2005:2) argue, "cognitive linguistics posits a universal set of cognitive abilities which serve to both facilitate and constrain the development of our conceptual systems and, hence, delimit what is possible to express in language.

The authors elicit the following constrains that serve as basis to our conceptualization capacity which reflects on the ways we make use of language: embodiment, environment, experience and perception.

Embodiment is a fundamental aspect of the metaphorical thought. The nature of our cognitive and sensorimotor apparatus constrains significantly the nature of human experience and conceptual systems. The way we reason is fundamentally bodily-based. The unfolding consequences of the tenet "reason is inextricably embodied" are the changes in the understanding of reason. Lakoff and Johnson (1999) argue that reason is also mostly unconscious, largely metaphorical and imaginative, emotionally engaged and is a capacity shared by human beings.

Environment and experience are also fundamental to the way we reason about the world. The ways we interact with and within the environment and the quantitative and qualitative aspects of our experience in the world provide basis that results in disquieting ties at the cognitive level.

Accoding to Lakoff and Johnson (1999), the detailed structures of our brains have been built up as a result of evolution and experience. Since metaphor is a matter of the body, the brain and the mind by cognitive linguists, we understand that the thinking metaphorically is expected to be regarded as universal and as being so, conceptual metaphors might be cross-linguistically widespread.

Perception is also another cognitive capacity which is grounded on embodiment and that provides a link between the world and our ideas. 
Also this capacity has evolved on the basis of neural perceptual apparatus which in turn evolved to allow us to function adequately in the world.

In this paper we will focus on the shared metaphorical concepts across languages. Nevertheless, some attention will be given to the dimension of variation referred to the ANGER concept, and to the use of a single word such as head, which presents a variety of meanings, manifested in several types of expression, but whose meanings are interrelated, via metaphorical and metonymic processes.

\section{Emotion: AS AN EVOLUTIONARY, COGNITIVE AND}

\section{LINGUISTIC PROCESS}

Emotions are one aspect of our mental life that has a major importance to our existence. They have been investigated under such disciplines as Philosophy, Psychology and Biology, to name some, and they all have shed lights on the particular understanding of how emotions relate to states of mind, body reactions, desires, motivation and perception.

In the evolutionary perspective many emotions are forms of adaptations that individuals have developed precisely to solve basic ecological problems that organisms have experienced. (http://www.plato.stanford.edu/entries/ emotion)

There are other concerns with emotions whose focus is to find the clues to the ties between emotion and the ways it is communicated to others. These bonds are thought to be controlled by mechanisms which operate below the level of awareness. (http://www.plato.stanford.edu/entries/emotion)

Taking into account the complexity of emotions, it should be understood that emotions are made up of complex processes which include cognition, neurological aspects, psychology and physiological reactions, action tendency and subjective feeling.

Based on the principles discussed so far, let us take a look at how the elements of emotions are manifested in different languages. Abrantes (2001:330) gives examples of cross-cultural expressions which license the metaphor ANGER IS HOT FLUID IN A CONTAINER in European Portuguese, English, German and French: 
European Portuguese: derreteu-se todo; estava a fervilhar de emoşão; é uma pessoa fria; tem o sangue quente.

English: she's got a bot temper; be cool; to boil with indignation.

German: ein hitziges Temperament haben; sich Schwarz ärgern; sei cool; dampf ablassen.

French: elle a le sang chaud; sois cool; bouillir d'indignation.

As we have seen in the previous examples, it seems that the underlying conceptualization of ANGER is quite similar in those languages. Although emotions in general are said to be heavily bounded on cultural experiences, there are some reasons to understand how in some unrelated languages similar forms of talking about ANGER do not vary so much. Kövecses $(2000 ; 2002 ; 2005)$ has approached this issue coherently taking into considerations the aspects of universality in metaphorical conceptualization giving explanation based on the ways in which the body functions interconnected.

To start with we should try to answer the following question "what happens when people get angry?" As a matter of fact there are different ways that the body uses to release anger. Most of the time people breathe faster, their muscles get tensed, their hearts beat faster, their faces turn red, their hands turn cool, just to mention some body reactions. "But anger must be released in the right way. Otherwise you' ll be like a pot of boiling water with the lid left on. If the steam doesn't escape, the water will finally boil over and blow its top." (http//www.kidshealth.org.kid/ feeling/emotion/anger.html)

It is interesting that even when trying to explain what anger is we make use of metaphorical and metonymic expressions. As Kövecses (2002; 2005: 40-43) points out it is an extraordinary situation that languages such as Japanese, Chinese, Hungarian and Zulu, for example, have conceptualized ANGER "in remarkably similar ways." If we are interested in finding those commonalities between languages in the ways ANGER is conceptualized then the author's suggestion is that we should start with the metonymies which are related to the concept. Kövecses (2002:163-174) exemplifies some ANGER metonymies which include:

BODY HEAT STANDS FOR ANGER

English: Don't get hot under the collar

Hungarian: heated argument 
Japanese: My head got bot
Chinese: My face was pepperly bot with anger
Zulu: I felt my beart getting hot
Polish: somebody's blood boil

INTERNAL PRESSURE STANDS FOR ANGER

English: Billy's just blowing off steam

Hungarian: (boiled the anger-with) He is seething with anger

Japanese: Anger boils the bottom of the stomack

Chinese: The anger qi (gas or fluid) is in one's heart

Zulu: He was so angry he exploded

Polish: to burst with anger

REDNESS IN THE FACE AND NECK AREA STANDS FOR ANGER

English: He got red with anger

Hungarian: His head turned red

Japanese: He turned red with anger

Chinese: His face turned red and his eyes blazed

Zulu: The chief went red with anger

Polish: Scarlet with rage

Deignan (1995) in her English Guides 7: Metaphor organizes twelve chapters which were labelled based upon themes such as: the human body, domestic animals, flavour and taste, heat and cold to mention some. The aim of the Guide is to show how the literal meanings of the words associated with those themes relate to metaphorical use.

We have selected, from Deignan (1995), the words fire, flame, burn, blaze, cool, and cold (coldly) which are associated with emotions to see how close their metaphorical meanings are to the Brazilian Portuguese equivalents. We believe that it is quite important for foreign language students to be aware of the use of metaphors in ordinary language and are part of our way of reasoning. If they understand this fact, they will see that many languages share metaphorical concepts and this will contribute to expand their vocabulary and will help them to make plausible guesses when reading or hearing new metaphors.

Deignan (1995:162-164) makes reference to some of the meanings of cool as to describe behaviour which is calm, confident or become less angry. ColD, for instance, is used to refer to behaviour that does not show emotion or friendship. Let's observe the examples below: 
What I believe we have here is a cool and clever criminal.

You should each make your own lives, and when emotions have cooled, see if there's a possibility of friendship.

He felt the tremor run through him, then the usual cold calm had abruptly replaced it; She looked at him coldly.

In order to illustrate the English and Brazilian Portuguese metaphorical meanings of words related to the emotions discussed above, we have used two corpus-based dictionaries, one from each language, namelly, The Collins Cobuild English Language Dictionary (1990) and Dicionário UNESP do Português Contemporâneo (Borba 2004). What seems very intriguing is the fact that the meanings both in English and in Portuguese are very similar. The entries below show how the words FIRE and COOL are used in English and Brazilian Portuguese to license the figurative notion of emotion.

\section{Dictionary ENTRIES}

\begin{tabular}{|c|c|}
\hline The Collins Cobuild English Language & Dicionário UNESP do Português Contemporâneo \\
\hline $\begin{array}{l}\text { FIRE } \\
\text { If you fire someone with enthusiasm or fire their } \\
\text { imagination, you make them feel full of enthusiasm about } \\
\text { something. Eg. He lacked imagination and could not fire } \\
\text { the imagination of others... p. 539; } \\
\text { Someone who is on fire with enthusiasm or passion is very } \\
\text { enthusiastic or excited about something. } \\
\text { FLAME } \\
\text { You refer to a flame of passion, desire, anger etc as a } \\
\text { way of referring to a strong feeling that someone has; a } \\
\text { literary use. Eg. The flame of passion that has been lit in } \\
\text { their souls. p. } 546 \text {; } \\
\text { BURN } \\
\text { If your face or your cheeks are burning, they are red because } \\
\text { you are embarrassed or upset. My cheeks would begin } \\
\text { burning like mad. p. 186; } \\
\text { If you are burning with anger, humiliation, etc, you are } \\
\text { very angry, very humiliated, etc. Eg. He had to sit there } \\
\text { burning with humiliation. p. 186; } \\
\text { BLAZE } \\
\text { If you say that someone's eyes are blazing, you that they } \\
\text { look very bright because the person is angry or excited; } \\
\text { a literary use. Eg. She turned and faced him, her eyes } \\
\text { blazing... Her eyes were at once blazing and bewildered. } \\
\text { p. } 137-138 \text {; } \\
\text { A blaze of something is a large and intense or exciting } \\
\text { quantity of it. Eg. ... a blaze of publicity ... He left the } \\
\text { office in a blaze of glory. p. } 138 \text {; }\end{array}$ & $\begin{array}{l}\text { FOGO Sm } \\
\text { [Ab] ânimo; vivacidade de espírito; entusiasmo: vinoha- } \\
\text { lhe [sic] aquele fogo de dentro, uma ânsia verdadeira de } \\
\text { viver; p. } 630 \\
\text { [animosity; liveness of spirit; enthusiasm: that fire was } \\
\text { coming from the inside, a real anxiety to live] } \\
\text { Animação; excitação; ardor: o fogo da paixão; p.630. } \\
\text { [vivacity; excitement; heat: the fire of passion] } \\
\text { CHAMA Sf } \\
\text { [Ab] ardor; entusiasmo: a chama do amor; p. } 268 \text {. } \\
\text { [heat, enthusiasm: the flame of love] } \\
\text { QUEIMAR Vt } \\
\text { [Ab] excitar; inflamar; as palavras o queimaram por } \\
\text { dentro; p.1157. } \\
\text { [to excite; to inflame: the words burned him inside] } \\
\text { Esquentar-se; afoguear-se: sentiu que as orelhas queima- } \\
\text { vam; p. } 1157 \text {. } \\
\text { [to grow hot; to redden: he felt his ears were burning] } \\
\text { Ficar irritado; zangar-se: fiz uma brincadeira e ele se } \\
\text { queimou; p. } 1157 \text {. } \\
\text { [to become irritated; to get angry: I said a joke and he } \\
\text { burned with anger] }\end{array}$ \\
\hline
\end{tabular}




\begin{abstract}
COLD
Someone who is cold does not show much emotion, especially affection; used showing disapproval. Eg. The baby who doesn't get any loving will grow up cold and unresponsive. $\rightarrow$ used of the way someone looks, speaks, or behaves. Eg. His voice was cold and decisive ... ... cold blue eyes. p. 265;

* COLDLY eg. It's your, I said politely, but coldly. p. 265 ;

\section{COOL}

Behaviour that is cool is calm and unemotional, rather than angry or excited. Eg. The Police drew praise for their $c 00$ handling of the riots. p. 312;

When a feeling or an emotion cools or when you cool it, it becomes less powerful. Eg. Her passion for Herold had begun to cool... She hoped that by Monday their tempers would have cooled. p. 313.
\end{abstract}

\section{FRIO Adj}

Que sabe conservar a calma; que controla os sentimentos: alguém deveria manter a cabeça fria e o senso prático; p. 649.

[that who keeps his temper; that who has his feelings under control: somebody should keep the head cool and the practical sense]

Que denota insensibilidade ou ausência de emoção; isento de paixão; impassível: Dona Leonor teve para mim um sorriso frio, quase hostil; p. 649.

[that who shows insensitiveness or lack of emotion; free of passion; insensitive: Ms Leonor gave me a cold smile, almost hostile]

Que não experimenta prazer ou que não tem desejo sexual; frígido; p. 649.

[that who does not experience pleasure or have no sexual desire; frigid]

Causado por uma emoção forte: o título me fez correr um frio pelos braços; p. 649.

[caused by a strong emotion: the title sent a chill down my arms]

\section{ESFRIAR Vt}

Diminuir o ardor de; acalmar: Titia achou melhor sair um pouco para esfriar sua raiva; p.533

[to diminish the heat; calm down: My aunt decided to go out for a while to cool down]

Perder o ímpeto; acalmar: Alex deixou os ânimos esfriarem antes de voltar para casa; p. 533

[to loose temper; calm down: Alex cooled down hism temper before coming back home]

Tornar-se insensível ou indiferente; perder o entusiasmo ou o ardor: Joana esfriou e nao quis mais vê-lo.

[To become insensitive or indiferent; to loose the enthusiasm or the heat: Joana cooled down and decided not to see him anymore]

\section{FRIAMENTE Adv}

Com frieza; com indiferença; desumanamente: são assassinados friamente, em nome do quê? p. 648 .

[with coldness; with indiference; inhumanely: they are coldly assassinated in the name of what?]

Sem envolvimento emocional ou calor comunicativo; objetivamente: tudo é mostrado friamente, sem paixão. p. 648 .

[without emotional feeling or communicative warmth; objectively: everything is coldly demonstrated, without passion]

\section{FRIEZA Sf}

[Ab] ausência de ardor, de emoção: um homem cultor do belo é, sem dúvida, um homem de paixões, sem frieza; p.649.

[lack of heat, of emotion: a man who cultivates the beauty is undoubtedly a man of passion, without coldness]

[Ab] ausência de emoção; indiferença; insensibilidade: foi diretamente ao assunto que a preocupava, com precisão e frieza; p.649.

[lack of emotion; coolness; insensitiveness: she went straight to her worries, with preciseness and coldness]

[Ab] ausência de desejo ou prazer sexual; frigidez; p.649

[lack of desire or sexual pleasure; frigidity] 
If we consider how close those meanings and examples are in both languages, we may definitely turn the figurative language a key element for foreign language learners. If we focus on vocabulary learning, we will surely come across a great deal of vocabulary building based upon metaphors and metonymies. We also believe that if the teacher guides figurative vocabulary sessions on unknown words which take into consideration basic senses and their extended meanings and stimulates students to connect concepts to those basic senses, students do have a chance to see the links between the items.

According to Scholes (2003), "no word or expression arises for no reason", that is, they all have some form of motivation and foundation. In line with Lakoff (1987), motivation is a central issue in learning, as it deals with "a central phenomenon in cognition". In this regard, Lakoff (1987) reminds us of what we have all experienced so many times and argues that motivated knowledge is easier to be retained. Consequently, the study of this motivation and foundation may facilitate acquisition of vocabulary by language learners, and it is up to the teacher to make learners more aware of how the language systems work, encouraging them to draw some conclusions.

The basic assumption of Cognitive Linguistic researches is that the different meanings of words and expressions are mostly derived from our perception of the world; this perception being based on our basic embodied experiences, largely elaborated metaphorically. Much of this conceptual system is strongly related to our spatial orientation. The concept of VERTICALITY, for example, is born of the fact that we have a body with the structure it has and that we live on a planet with gravity like the Earth, which enables us to stand erect, with our eyes at the top and our feet underneath, pointing in a given direction. Thus, notions such as up-down, inside-outside, front-back, core-periphery, beginning-end are based on our canonical position and may generate several other concepts of spatial orientation. For instance, the metaphors HAPPINESS IS UP/SADNESS IS DOWN, HEALTH AND LIFE ARE UP/SICKNESS AND DEATH ARE DOWN are correlated with Man's posture or that of any animal that stands erect when well and happy and lies down when sad, or stands when healthy and alive and lies down when sick or dead, respectively. 
Nevertheless, such aspects/processes are so natural and run-of-the-mill that they normally go unnoticed. That is, many metaphorical expressions are used automatically, not requiring any effort for interpretation, and are part of the mind set of a given linguistic community (Lakoff and Turner 1989). A single lexical unit (e.g. head) may be used in several different situations in our daily lives, without our becoming aware of its metaphoric nature. For example: the farmer counts heads of cattle; we toss for heads or tails; the hammer hits the nail on the head; cowboys head off into the sunset; universities and companies have heads of department; the imprudent may dive head first into a relationship; we all know people who are headstrong, who don't use their heads and who have nothing in their head.

The main issue is that understanding and using this diversity of meanings is a natural process for a native speaker, but very often presents considerable difficulty for learners of a foreign language. According to Lakoff (1987), the different meanings of a single word form a category, wherein each meaning is equivalent to a member of this category. The author explains, however, that there are meanings which are more central and others that are less central. The most central meaning is called prototypical and this forms the root from which the other meanings of a given word derive, according to Brugman and Lakoff (1988). A polysemous item is, in the view of these authors, a category of radial meanings, with a central member and a network of links with other members of that structure. The links between these members are not arbitrary, but rather systematic and based on principles. Although the several meanings of a polysemous item are related to one another, it is not true that they are necessarily connected to the same central member. On the contrary, it is generally the case that each meaning can generate, through a metaphorical or metonymic process, for example, another meaning, unrelated to the central member of the radial structure.

In the next section, we shall see how an apparently simple item, like the noun HEAD, which, as it refers to a part of the body, is assumed to be highly productive in several linguistic communities, with similar structures and uses, presents a variety of meanings, which are manifested in several types of expression, encompassing not only metonyms (he is a good head) and idiomatic expressions (be laughed his head off), but also proverbs, popular sayings, maxims, adages, aphorisms or clichés (better to be the head of a dog than the tail of a lion, heads will roll, when the head is sick, the whole body is sick), analysed indistinctly. 


\section{HEAD: FROM OUR BODY EXPERIENCIES TO LANGUAGE USE}

Lima (1995) analysed conventional metaphoric expressions with the noun "head" in English and in Portuguese, aiming at identifying the representation of the body part head in the conceptual system of both linguistic communities. The author identified nine conceptual metaphors based on our experience with our head as part-of-the-body on various levels: five based on man's and four-legged animals' physical aspects (THE HEAD IS A UNIT, THE HEAD IS A ROUND OBJECT, THE HEAD IS AN EXTREMITY, THE HEAD IS A SOURCE and THE HEAD IS A POINT OF REFERENCE), one in its coordinating function (THE HEAD IS A LEADER), one in its vital function (THE HEAD IS A VITAL POINT), and two relating to the mental processes concerning reasoning and emotion (THE HEAD IS A CONTAINER and THE HEAD IS A MACHINE). As shall be seen, several expressions with head illustrate spatial orientation, which seems to be linked to implicit notions of movement, but other correlations that mankind draws between experience with the body, other entities and historic facts, are also illustrated in several expressions.

We present below only the data relating to English, but wish to make it clear that in addition to the metaphors occurring in both languages, there is a considerable number of similar expressions they share.

THE HEAD IS A UNIT: Two ideas of unit are present in the expressions found: the unit of quantification and the unit of measurement. The idea of quantification stems from the fact that, prototypically, elements from the animal kingdom have a single head. Any animal with more than one is conceptually a monster. In mythology, the presence of polycephalous beings symbolized the manifestation of supernatural powers (Chevalier and Gheerbrant 1991). Although there is some manifestation of mythology in language, it is the natural prototype, i.e. beings with a single head that predominates. In addition to being single, the HEAD has an essential role as a means of distinguishing people and animals. Lakoff and Johnson (1980) explain the functioning of what, for them is the metonymy THE FACE FOR THE PERSON: "if anyone wishes to know the appearance of a given person and a portrait of that person which fails to show the face is given, they will continue in ignorance of that person's identity; if, however, a passport photo showing only the face is given, then they will be satisfied" (Lakoff and Johnson 1980:37). It is interesting to observe that no other part of the body has the same relevance. These phenomena probably explain the 
use of certain expressions in which HEAD is used for people or animals considered numerically.

The notion THE PART FOR THE WHOLE is used for quantification, in an attempt to call attention to the unit factor. Thus, the HEAD is a unit to quantify cattle, people and prices (I've got 50 head of cattle; Let's count heads before we leave; It will cost \$9 a head). Note that the expression "the head" carries a heavy loading of deictic reference, to the extent that, at a lunch "head" refers to one who eats, at a concert to one who hears, at a play, to one who watches and so on.

The idea of measurement is related, in general terms, to an idealized size for the human or equestrian head. Other body parts have been used as a measurement. The foot and the inch, initially representing the size of the king's foot and thumb respectively, have today taken on fixed values within a duodecimal system. The HEAD, on the contrary, has no fixed value, but only an approximate spatial notion. Apparently a paradox, it can represent a very small or very large difference, and can bring an implicit vertical or horizontal spatial concept. In a horse race, the measurement is horizontal and represents a very small difference, probably by referring to the total length of the course ( $M y$ horse won the race by a head). With humans, the measurement is vertical and represents a large difference (She's half a head taller than her brother).

Moreover, there are two notions of measurement in the expressions, one concrete and the other abstract. The concrete one indeed refers to head size, as mentioned above, in which horses can win a race by a head and height differences between people may be measured in portions of the head. Through the metaphor THE LABOR MARKET IS A COMPETITION, this notion generates expressions such as "head to head", conveying the idea of considerable competition, involving people or companies in the marketplace (The competitors are head to head), and through the metaphor GOOD IS UP, generates statements that express qualitative aspects of books, articles, magazines, wines and even people (Our articles are really bead and shoulders above yours; As far as she was concerned, her husband stood head and shoulders above any other man; This wine is head and shoulders above that one).

THE HEAD IS A ROUND OBJECT: It is common for us to name things according to their similarities in shape or function with the human body. The shape of the head, as perceived by humans, is typically round. One 
may observe in expressions that any round object or round part of an object may metaphorically be called a head, provided it satisfy one of the following criteria: position as an extremity, formation of an isolated whole or being one of two parts.

Thus, the rounded extremities of long bones are commonly called heads (bead of the femur; head of a humerus), as are certain components of equipment (head of a tape recorder), geographical features (head of a bay; head of a cave; head of a gulf). Any rounded foliage, such as the canopy of trees in general, flowers and clover, seems to be called "head", irrespective of whether or not it is a vegetable (head of lettuce, head of a cauliflower, head of garlic, head of a tree; flower head; (lover head).

THE HEAD IS AN EXTREMITY: As the physical human experience of one's own body serves as a basis for many metaphors, things have body and head, seen as opposing extremities. The head is seen as an extremity opposing the foot, the tail or the body, thus generating several other image schemas: top-bottom, front-back, start-end etc.

The expressions show several notions of extremity, which are superior part, anterior part or separate part from the rest of the body. For example, the head in opposition to the foot denotes a vertical spatial notion, above and below, generating several expressions (head of the mast; head of the sail; head of the pole; head of the pile; head of the page; head of the book; head of the list; head of the mountain). Note that most of these expressions are also possible with foot (foot of the mast, of the sail, of the page, of the mountain etc.). Furthermore, depending on the metaphor, the same expression may present different but correlated meanings. For example, "the head of the page" may refer to both the header and the upper part of the page, in opposition to the lower portion, i.e. the foot of the page (not to be confused with footnote, which, incidentally lies at the foot of the page). The same is true of "the head of the list", which may be both the upper portion of the list and the first item on the list, i.e. the item that generates the list, enabled by THE HEAD IS A SOURCE metaphor.

The notion of head as opposed to tail is horizontal, that is, anterior part opposite posterior part. Some things have two indistinct extremities, such as corridors, bridges, barrels, drums etc. (heads of a hall; heads of a bridge; heads of a drum; heads of a barrel; heads of a hand-reel; heads of a cask). Other expressions generated by this notion (head of the cortege; head of the 
procession; head of the queue; head of the regiment; head of a column (of soldiers); bridgehead; head of the comet) convey an implicit notion of movement, the direction of which is also horizontal, forwards, determined by the head. It is analogous to the movement of an animal walking. Although a cortege, procession, regiment, a column or line grow in a direction opposite from the head, the implicit movement is forward, determined by the head, which the rest follows.

The head opposite the body is partial and static. The human body, in its most generic description, is divided into head and body. It is common to see human figures presenting only two parts, in signs, for example. The large field of tools, equipment, parts and other such objects is full of names designating parts of the body due to their physical or functional resemblance to living beings. Thus, these materials have mouths (e.g. mouth of a tube), teeth (e.g. teeth of a $\operatorname{cog}$ ), feet (e.g. feet of a table) and, especially, head. In general, extremities of long objects are called heads (head of the arrow; spear head; head of the hammer; head of an axe; head of a hatchet; head of the nail; head of the bolt; head of the pin; head of the screw; head of a knitting needle). These extremities convey both the notion of an upper part and that of a frontal part - an arrowhead is the foremost extremity, understood thus when in the attack position; the head of the nail is the extremity that is uppermost when the nail is being hit by a hammer.

Beds, graves and tables also have heads (at the head of the bed; at the head of the grave; the head of the table). These are the most important extremities as this is where the head lies, whether literally (body part) or metaphorically (the leader, the most important person) enabled by THE HEAD IS A LEADER metaphor. At a table, the reference is the extremity where the head, the leader, the most important person sits. It is a narrow extremity with space for only one person. This place is special, as, in addition to enabling the occupant to see all those seated at the table, both to the right and the left, it also enables the individual to be seen by all. In such a privileged position, one can gain control of the situation. In this sense, this explains the legend of why King Arthur created a round table, so that, with no 'head', there would be no disputes between the knights, and everyone would sit to discuss their problems and peace plans on equal terms.

THE HEAD IS A SOURCE: The head-foot opposition generates a series of secondary ideas. In addition to being the highest extremity, the HEAD is also 
seen as the initial part of the body and source of thought and inspiration. For instance, rivers and lakes have a head. It is the part seen as the source, the beginning and from which everything originates, grows and takes shape, with or without the help of affluent rivers. The metaphor may also occur as a point of abstract origin, that is, the generator or causer of an idea or problem (His few remarks hit the nail on the head; I will go to the head of the matter; heads of a sermon, discourse, speech...).

THE HEAD IS A POINT OF REFERENCE: The metaphor THE HEAD IS A POINT OF REFERENCE is an orientational metaphor, basically containing the spatial notion of head-foot/tail opposition; sometimes it means above as opposed to below to determine order/disorder; sometimes beginning opposed to end; sometimes one thing or another; or, simply, the maximum point that can be reached in a career, skill etc.

The canonical position of man seems to serve the model for establishment of that which is normal, that is, heads above, feet below. Disorder or abnormality can, then, be represented by the inversion feet up, head down, as illustrated by several expressions (She rushed out and left her room head over heels; He tripped over the cat and fell head over heels; I'll do anything, I'll even stand on my head for you to come with me; The clothes made by this company have stood the whole fashion world on its head). Some of these expressions do not necessarily mean the fact described by the adverbial modal clause: fall head over heels or fall heels over head are true hyperbole when they represent a person hitting the floor. To leave a head over heels is to leave it untidy, with several objects out of place. To turn somebody's life on its head is to cause somebody to leave a regular, normal, calm life and live a wild, confused, stressful or surprising lifestyle. Not know if one is on one's head or on one's heels is an analogy to upside down, and occurs when things are somehow disorganized, upside down, so that one no longer knows what is in the correct position - the environment or the individual.

The head seems to be seen culturally as the beginning of the animal body; the feet are the end when the model is human and the tail when the model is a quadruped animal. The identification of these reference points is important in order to gain a sense of orientation. Without identification, there is no way to understand things. Something a without head or tail is confused, meaningless (no one was able to make head or tail of his fancy story), because its limits have not been identified, from head to foot, toe describes 
something that affects the whole body (She was dressed in black from bead to foot; He examined the house from head to toe).

In addition to expressions with the idea of opposing extremes like beginning-end, up-down, normal-abnormal, tidy-untidy etc, there are other expressions with points of reference, indicating the pinnacle, most important or best of something. Thus, one can be at the highest point (Our candidate is at the head of the poll in six states), get there (His career came to a head when he was appointed Dean that year) or go over the top (Don't you dare go over my head again).

THE HEAD IS A LEADER: Any organization is seen in the conceptual system of the two languages studied as a human body, comprising head, body and members (student body, members of a cooperative, head of the department). The very term 'corporation' comes from 'corpus' (body) and is applied to the formation of groups of people with common interests. In this metaphor, as with the human body, the head is the most important part, responsible for coordination of the body. In addition, its physical position generates the notion of hierarchy present in corporations, which, together with the metaphor STATUS IS UP, generates a series of expressions. Those referring to jobs and posts are highly productive (Head of State; the head of government; the head of the revolution; the head of the rebellion; the head of the department; the head of the school; the head of the committee; the head of the family; the head of the house; the head of the Roman Catholic Church; chief cowboy; head of the herd).

The importance of HEAD, well illustrated by the proverb "better to be the head of a dog than the tail of a lion", is repeated in day-to-day expressions such as "Father gave me my head to run his business" or "Each time we give you your head, you do something stupid", which means to allow somebody to be responsible for their own life, making all the decisions relating to their life or work, according to their own rationale, interests and will, or in $A t$ the head of (affairs), which is to be in the position of HEAD with the role of coordinating everything submitted thereto (Miss McLeod is at the head of her father's company, Dr. Watson is the head of the ward).

THE HEAD IS A VITAL POINT: In the human body, the head, in addition to the brain, contains the external organs responsible for breathing and feeding, essential for remaining alive. There are several expressions enabled by this metaphor related to such aspects, to refer to, for example, financial status in a metaphorical context in which DEBTS ARE CONTAINERS WITH WATER 
(At this inflation, my salary is hardly enough to keep my head above water). In this meaning, the head determines a measure of financial survival: above is survival, below is ruin (He is in over his head in this new commercial enterprise; With his parent's inheritance he was able to raise his head again).

One of the ways of speaking of consequences of an undesirable ideological stance comes from the combination of this metaphor with STATUS Is UP. Any stance contrary to the interests of leaders may cause the loss of one's head: it may be cut off, it may be used to pay for some dissatisfaction caused, or it may be desired by someone. The allusion to historical aspects is manifested when there is opposition of ideas, the consequence of which is loss of one's life. For example, the guillotine eliminated figures considered undesirable by the French revolutionary government of 1789 as they failed to share the same ideas or for having been responsible for unsuccessful actions, a fact that inspired Adolf Hitler to use the phrase heads will roll, in the Second World War; John the Baptist was decapitated upon the whim of a young woman, whose phrase I want his head on a platter, is still used today for those who cause consternation for saying undesirable things and by opposing; in allusion to more ancient happenings, the Celts displayed the head of their enemies as a trophy (He went to Africa as a mercenary - a tough adventurer with a gun for hire. His exploits put a price on his head throughout most of Africa)

Responsibilities are very heavy things (RESPONSIBILITIES ARE WEIGHTS) and, for acts judged to be wrong, whether they be criminal or not, the consequences can fall on one's head (Take down the fence if you want to, but on your head be it; I'm willing to let them continue working if they do the job properly, but the first mistake they make will bring all my anger down upon their head; If your plan goes wrong it will be on your own head). In other words, the HEAD is a target for harsh punishment, as it may cause the taking of life, not only in the literal sense, but also in the several conceptions of life which exist culturally, such as LIFE IS POWER. In several expressions, there is also allusion to some historical aspects, such as the hangman's noose, used for centuries as capital punishment of criminals (he has the inspector's suspicion hanging over his head). As seen above (THE HEAD IS A SOURCE), if the origin, which is the source, is destroyed, everything else will be destroyed. So, to defeat someone or something, it would seem to suffice to hit their head (We must find a way of knocking their plan on the head). 
Man would seem to be exposed to danger with a certain frequency. To place one's head in danger is to run the risk of losing liberty, career, position or even life. Some forms of exposure to danger are explicit in expressions, for example, an individual can place his head under the guillotine (Put your bead on the line and make a decision); in the lion's mouth (He is well known to the police, yet several times he has placed his head in the lion's mouth by going to visit bis friends in prison) or knock it against a wall (stop insisting on the impossible, you're banging your head against a brick wall).

Metaphors related to reasoning and emotion: As observed in the expressions, there two more metaphors strongly present in the conceptual system of the languages studied: the head is a machine and the head is a container. They seem to be part of a larger metaphor, THE HEAD IS A MACHINE WITH A CONTAINER, in which a human head is seen as a machine, fed by information which is processed and the product of which is manifested in human behaviour. The expressions reveal several aspects of our idealized cognitive models regarding what a machine is (its structure, the characteristics of each part) and the conditions necessary for its smooth operation (processing material, source of power, temperature). In the case of the head machine, the source of input is the container, where information is placed, that is, the raw material; the processor, where thought takes place, is the machine's workings; and the final product of this processing may be subject to control by reason or emotion ${ }^{1}$.

Generally, a machine contains a container where raw material is placed for processing. To obtain a given end product, two conditions are necessary: the machine must be turned on and its container must contain raw material. A machine that is turned off does not process. Nevertheless, to obtain a quality product, other factors must be considered, such as ideal conditions of the machine and container, the type of raw material and fuel used and temperature etc. Several of these details are described by several expressions.

1. The exact limit where something ceases to be reason and becomes emotion or vice-versa is not well defined. Although the definition of reason encompasses wisdom, that of emotion does not encompass foolhardiness, but, to a certain extent, foolhardiness seems to be under the control of emotion. Not of emotion as an intense reaction by feelings, but as opposed to rational thought, to reason. In this regard, emotion and foolhardiness are highly related: foolishness always occurs when emotion is in control and emotion seems to control when there is foolishness. It is in this sense that Lima considered, in her study, that emotion encompasses foolishness. 
Before analysing the head as a machine, which is the greater metaphor, it is interesting to see how this container is characterised in expressions:

THE HEAD IS A CONTAINER: There is a range of expressions showing that the head is understood as a container (Who put this idea into your head?, He suddenly took it into his head to buy a big new car, He told his mother not to get ideas into her head, She's been filling my head with new ideas). Some things pass through this container, they arrive, enter, stay or leave (He just stood there watching - it never entered his head to help me; Give me a number - the first one that comes into your head; He holds everything he reads in his head), others are hard to hang on to (it's too much information for me to hold in my head). In the case of a defective container, with holes, for example (bis head is like a sieve; he's talking through a bole in his head), nothing will be retained and it will become empty.

The ideal size of the container is not clearly defined. It is known, however, to vary from person to person, and that A LARGE CONTAINER IS GOOD and A SMALL CONTAINER IS BAD. The container may be sufficient to contain a person or even a larger object, like a car or a castle (Try to put this girl out of your head, she doesn't like you. Can't you get this castle out of your head?). Nevertheless, some containers are quite small (knothead, beanhead, chickenhead), with next to no space. A small container cannot hold enough raw material for good processing. The low volume of raw material (in the case of small containers) or excess (when the head is full) would not seem to produce anything under the control of reason. Thus, to have a good machine, there must be a large container with plenty of space, without, on the other hand, filling it, as shall be seen below.

Some things fit in the head and others don't (thinking of him as a hero is an idea that just won't fit in my head). However, it is not know exactly if the limitation occurs due to the size or the shape of the container, or if it is related to what one wishes to place therein, as there are some things that simply won't fit in anyone's head (sorry, but nobody will get that into their head). There is also not much information about opening of the container. Some things enter, others don't (be couldn't seem to get it through his head that his wife was really leaving him); very high-level information (some are really very high) only enter those heads that are able to reach the heights, otherwise, the information is above them (all this sort of thing is well above my head). The opening seems, however, to be in the top of the container. 
In addition, we speak of the top of the head, from which it is possible to remove something highly processed (I can't give you the figure off the top of my head, but it's around, say, 500).

The expressions do not reveal the ideal consistency, but make it clear that A HARD CONTAINER IS BAD. It must be malleable, flexible, as it is possible to make someone's head. Nevertheless, not all head shapes produce a good result. For example, using drugs to fill one's head does not lead to a good result, as drugs are not an acceptable fuel for the machine, as shall be seen below. The type of material of the container seems to be fundamental for a good machine. It must be resistant and strong, but cannot be hard. There are, however, hard heads, those made of bone (Four sons, all bone-heads) or cement (blockhead) and bullet heads, but it would seem that in containers of this nature, nothing can penetrate (no use talking to him, he is a hard headed person).

The contents of the container are the raw material processed in the machine. For smooth operation of the machine, i.e. to obtain a product under the control of reason, two aspects concerning raw material are illustrated by the expressions: quantity and quality. Quantity of raw material in the container determines smooth operation of the machine: if there is an insufficient quantity of raw material, because the container is small, the machine fails to produce a good end product; if its empty, with nothing inside, hollow or full of air or wind (Catby is empty-beaded, she is always talking rot; My sister's husband is an airbead; Linda was a bubblebead; I don't want to see that balloon head again) there is nothing to process, consequently the machine doesn't work.

Regarding the quality of raw material, this is highly varied and also important for smooth operation of the machine. The examples enable us to identify several things that are placed in or removed from the container. In addition to abstract things, like ideas, thoughts, knowledge, facts etc., there are also concrete items, like cars, castles and people. Some expressions illustrate inappropriate types of content, which may characterise the container itself. This cannot be too soft or weak (Don't listen to him, he's soft in the head; You must be weak in the head if you think I'll agree to that), but nor can they be too hard (Kid, you got rocks in your head). To place rocks in the head makes the container hard, inflexible, consistent with A HARD CONTAINER IS BAD (have rocks in thelone's head). A soft had is also bad (bananahead, cheesehead, fathead, lardhead). 
THE HEAD IS A MACHINE: The head is a machine that one may or may not use (It is not a difficult problem, just use your head), sometimes to do very specific tasks, such as mathematical calculations, for example (He is a young man with a real head for figures), or in which a given idea is developed, like a hammer (these facts have been drummed into his head). It is sometimes necessary to touch it so it will work (He was scratching his head, because he did not expect that kind of problem). However, if overworked, the machine may break down or require maintenance (Now it is all right, but I racked my brains to find the solution). That's why, when dealing with a sizeable problem to solve, we use more than one head (This is a difficult problem to solve, we'd better put our heads together.); what one machine lacks, others may have, distributing the workload and thus leading to a better result (I'll ask my brother to belp; two heads are better than one).

Expressions in both English and Portuguese as in general terms show a series of machine-like characteristics. The machine may be good (we need some good heads on the project), and may perform specific functions (For this job, we need someone with a head for heights; He has a good head for business; I have no head for physics). It is hoped that the head-machine presents a final product under the control of reason. This seems to occur only when conditions are perfect, as anything wrong or odd, for example, an unstable machine, may produce emotion (don't take any notice of old Bill. He's not quite right in the head). In order for it to work, then, it would appear to require being in the right place (he is the perfect man for the job, for he has a good head on his shoulders); but that's not all, it must be firmly attached, by screws (I believe he is doing the right thing, for he has his head screwed on properly). In other words, we have the underlying notion that "the stable machine in the right place works well". Any alteration in this regard may cause malfunction of the machine, i.e.: (a) when the location of the machine is not known (this only happens when it is in the wrong place) it cannot be used, as shown by the expressions (I do not know where my head was, when I did that). (b) when it is in a location other than it's correct position, such as in the air, in the clouds or elsewhere, it is also unusable (She has her head in the clouds most of the time; He left his head at home today). (c) to remove it to bury it in the sand (Face the facts instead of burying your head in the sand.) or hide it (When I realized my mistake I hid my head); to put the head on the ground is to lose full control of reason (no use talking to her, she's head over heels in love with him). (d) The lack of a screw or even one of them being loose may create instability and cause problems. One such problem is destabilization of the machine 
(He must have a screw loose, acting that way). The instability of the machine, created by a problem with the screws may cause it to spin, uncontrollably (Since he saw that girl his head has been spinning).

Still with regard to screws, a prolonged action may cause one to come out or loosen, causing loss of contact with the machine (head off) and causing loss of control. Actions continue, then, in an exaggerated way, without limits (laugh one's head off; scream one's head off; talk one's head off). This metaphor is highly productive and enables lexical creations, that is, several verbs, in addition to conventional ones, may be used in the expression " $\mathrm{X}+$ one's head off".

Unsuitable fuel would totally deregulate the machine, causing full loss of control by reason. Alcohol, drugs, vanity, jealousy and envy are basically inappropriate fuels revealed by the expressions (hophead; hash head; cokehead; hay head; juicehead). Alcohol and drugs, elements external to the body, have uncontrollable effects once they reach the head, even causing it to fly (The champagne went straight to my head; he flew his head). Vanity, jealousy and envy are produced when status symbols like jobs, awards and disappointments are in the head (His nomination for the head-master's post went to his head). A good machine, however, seems to prevent such elements from penetrating it $\mathrm{He}$ is a sensible man and his position will never go to his head). The consequences of using such fuels are varied: for example, vanity may cause one's head to increase in size (the promotion gave him a big head; since the boss praised her work she's been suffering from a swollen head). These alterations do anything but contribute to high performance by the machine. Each machine has its own characteristics, as seen above and the bigger the machine the better. However, this is only a good thing when naturally so, that is, when it is manufactured with such specifications. If there is any alteration a posterior, the result is negative. Thus, to have a big head, or to be a big head, due to vanity or alcohol, causes disturbances in the machine. The effects of alcohol are lexicalised: they can turn the head to stone or cause an increase in its size (the day after, he arrived early in the morning but completely stoned out of his bead; the rum gave me a big head next morning).

Another important factor for smooth operation of the machine would appear to be temperature. According to expressions in both languages, at a high temperature, reason fails to function, giving way to total control by emotion (There was a time when he was regarded as a hothead, a man whose 
career could be blunted by his rashness). It is therefore important to keep the machine cool (She managed to keep a cool head in a difficult situation). The ideal is to keep it cool and clear (keep one's level/cool/clear head). However, when it heats up, you can leave it to cool off (You'd better not say a word until you get a cool head) and reason can once again prevail.

When something fails to work as expected, i.e. with reason in control, there is a need to see what's wrong with the machine (You ought to have your head examined, buying an old car as bad as that one). Sometimes, the problems appears to be simply due to the fact that the machine is not being used (You're out of your head if you think I'll do that; My father's gone right off his head). In these cases, there is obviously no control by reason.

In summary, mental processes seem to take place inside the HEADMACHINE, the expected end product of which is controlled by reason. For this to take place, however, the machine must be on and in perfect working order, that is, at the right temperature, running on a compatible fuel and containing an on-spec container, with raw materials capable of being processed. Any alteration in these optimum conditions may alter machine operations, causing reason to be shut down and consequent take-over by emotion or foolishness.

According to Lima (1995), it is possible to structure the meanings of the noun head in the following network (Figure 1). Note that the network is the same for both English and Portuguese, although some of the nodes may be more productive in one language than in the other. 


\section{The MeAnings of HEAD}

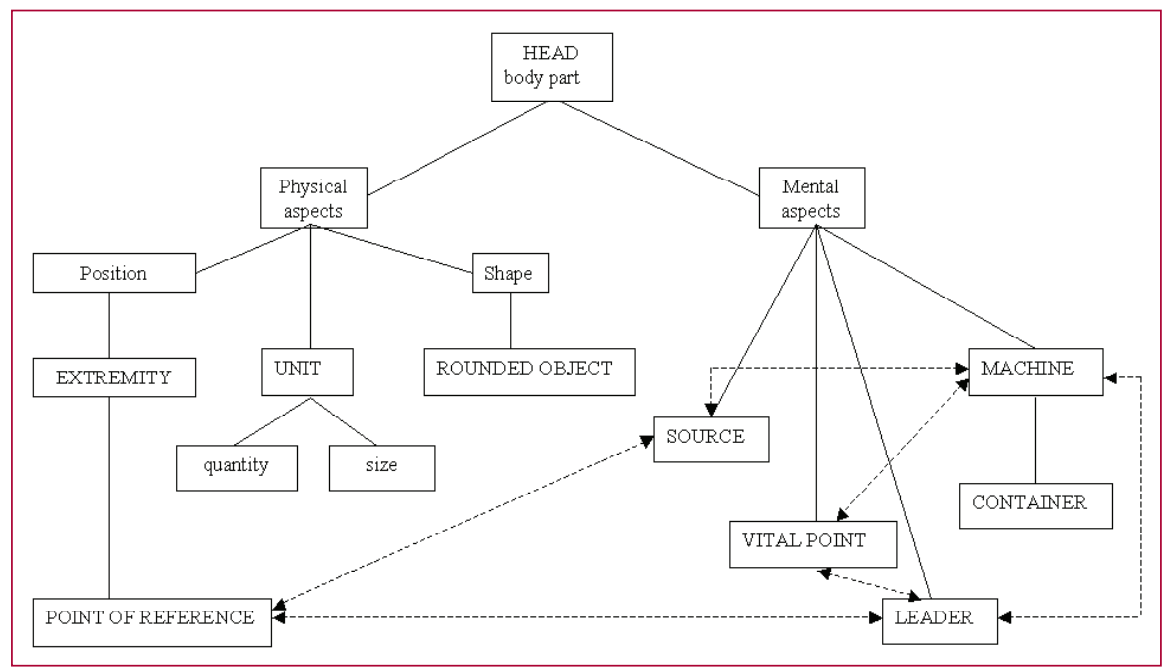

Figure 1: Network of the meanings of the noun HEAD.

\section{FinAl REMARKS}

In view of the results derived from the analysis, it seems that there are metaphorical concepts with significant cross-cultural correspondence. Concepts such as HEAT, COLD, and HEAD appear to be quite similar in different languages. The linguistic expressions licensed by those concepts can be used as tools for identifying the reasons for the correspondences.

Littlemore and Low (2006) recommend some steps to be followed in order to understand and remember the meaning of unknown words. The steps are:

identify familiar or basic senses of the words; ask about the shape, components, structure and functions of the entities; use the context to establish whether the answers suggest an appropriate meaning; if it does not, ask about peripheral detail, associations, and concepts known to be involved in metaphor and metonymy in the L2 (journeys, containers etc.); use the context again. (Littlemore and Low 2006:25).

Although this teacher-led intervention is used in very controlled situations, it has been proved very fruitful once it promotes understanding and retention of vocabulary. The process of teaching figurative language 
explicitly implies as Littlemore and Low (2006:54-60) suggest the activation of the student's knowledge of the source domain, the use of associative fluency in case of gaps between domains in the student 's native language and the foreign language, the use of analogical reasoning to establish similarities and relations between concepts that can be used to understand other concepts and establish associations between source and target domains.

As teachers of foreign languages we should try to take advantage of the multi-cultural and multi-lingual aspects of metaphoricity to encourage us to expand the scope of our actions in the field of teaching so that we evaluate our teaching praxis, revise and prepare teaching materials which focus on varieties and similarities between languages.

Recebido em setembro de 2009 Aprovado em abril de 2010

E-mails: emiliapfarias@gmail.com plenz@uece.br; plenz@renorbio.org.br

\section{REFERENCES}

Abrantes, A. M. 2001. Da vida e outras viagens: a relevância das metáforas conceptuais na abordagem de uma língua estrangeira. Mátesis, 10, 319-332. Portugal:UPC.[On-line] Available at: <http://www2.crb. ucp.pt/Biblioteca/Mathesis/Mathesis10/V/319.pdf. $>$

Acess on: 06 oct. 2008.

Borba, F. S. (Org.) 2004. Dicionário UNESP do português contemporâneo.São Paulo:UNESP.

Brugman, C. \& G. LAKoff. 1988. Cognitive topology and lexical networks. In: Small, S.L., Cottrell, G.W.; Tannenhaus, M.K. Lexical ambiguity resolutions: perspectives from psycholinguistics, neuropsychology, and artificial intelligence. San Mateo: Morgan Kauffman Publishers Inc.

Chevalier, J. \& A. Gheerbrant. 1991. Dicionário de símbolos. Coord. Carlos Sussekind. translation by Vera da Costa Silva et al. 4.ed. Rio de Janeiro: José Olympio.

CoBuild, Collins. 1990. ENGLISH LANGUAGE DICTIONARY. London: Collins. 
Deignan, A. 1995. English guides 7: metaphor. London: The University of Birmingham; Collins Cobuild; Harper Collins Publishers.

Farias, E.M.P. \& L.A. Marcuschi. 2006a. A linguagem e o pensamento metafóricos. In: Macedo, A.C.P.S. \& Bussons, A.F.(Orgs). Faces da metáfora. Fortaleza: Expressão Gráfica e Editora.

Kövecses, Z. 2000. Metaphor and emotion. Language, culture and body in buman feeling. Cambridge/NewYork: Cambridge University Press. Paris: Editions de la Maison des Sciences de L'homme.

2002. Metaphor: a practical introduction. Oxford and New York:

Oxford University Press.

2005. Metaphor in culture: universality and variation. Cambridge: Cambridge University Press.

Lakoff, G. \& M. Johnson 1999. Philosophy in the flesh: the embodied mind and its challenge to western thought. New York: Basic Books. 1980. Metaphors we live by. Chicago: Chicago University Press.

LAKoff, G. \& M. Turner. 1989. More than cool reason: a field guide to poetic metaphor. Chicago: The University of Chicago Press.

LAKOFF, G. 1987. Women, fire and dangerous things: what categories reveal about the mind. Chicago, London: The University of Chicago Press.

LAKOFF, G. 1990. The invariance hypothesis: is abstract reason based on image schemas? Cognitive Linguistics 1, 39-74.

LimA, P.L.C. 1995. Usando a cabeça: um estudo da representação do substantivo "cabeça" no sistema conceitual das línguas inglesa e portuguesa, através de expressões metafóricas convencionais. Fortaleza: Universidade Estadual do Ceará. (M.A. thesis).

Littlemore, J \& G. Low. 2006. Figurative thinking and foreign language learning. Great Britain: Palgrave Macmillan.

Mey, J. 2006. Metaphors and activity. Essays on metaphor in language and thought. D. E. L. T. A. 22 Especial: 45-65.

Scholes, J. 2003. OK! Curiosidades divertidas do inglês. Rio de Janeiro: Campus.

Strugielska, A \& M. R. Alonso-Alonso. 2005. Idiomatic expressions in multicultural integration: a cross-linguistic perspective. [On-line] Available at: < http://www.inter-disciplinary.met/ati/diversity/multiculturalism/ mcb1/strugielska\%20paper.pdf $>$.

$<$ http://www.plato.stanford.edu/entries/emotion >. Access on: 10 jun. 2008.

$<$ http//www.kidshealth.org.kid/feeling/emotion/anger.html $>$. Access on: 10 jun. 2008. 